Н.М. Кізілова, Н.Л. Ричак

Харківський національний університет ім. В.Н. Каразіна, Харків

\title{
ІНФОРМАЦІЙНЕ СУПРОВОДЖЕННЯ СИСТЕМИ МЕНЕДЖМЕНТУ ВОДНИМИ РЕСУРСАМИ НА УРБАНІЗОВАНИХ ТЕРИТОРІЯХ
}

Проблеми дефіциту води зростають в останні роки майже в иілому світі в зв'язку зі зростанням чисельності населення, особливо на урбанізованих територіях, а також у зв'язку з масштабними геофізичними проблемами, такими як глобальне потеплення клімату, фізичні зміни в тропосфері, щзо приводить до суттєвих змін в локальних екосистемах. Відповідні проблеми, щяо постають перед суспільством, мають міждисииплінарний характер $i$ тому потребують відповідного підходу до їх розв'язання. В даній роботі приведений огляд найбільи вагомих досліджень з иієї тематики та запропоновані моделі і методи до обтрунтованого кількісного підходу до розв'язання найбільш суттєвих задач з використанням баз даних геофізичної, гідрологічної, екологічної, економічної інформації, ії обробки i аналізу методами статистики, математичного моделювання, механіки рідини та системної динаміки, $i$ поширення висновків для своєчасного прийняття рішень на різних рівнях, порівняно з досвідом світової практики.

Ключові слова: геоінформатика, екологія, урбанізована територія, водні ресурси, менеджмент, математичне моделювання.

\section{Вступ}

Дефіцит води, який зростає через збільшення чисельності населення, розвинення економіки, поліпшення рівня життя та посилення захисту навколишніх екосистем, є однією із найскладніших проблем у світі [1-3]. За даними UNECE ${ }^{1}$, споживання прісної води на душу населення у 2014 р. було від 554 (Ісландія) до 1118 м (Малаві). Адміністрації великих міст стикаються 3 ще складнішою ситуацією дефіциту води через швидку урбанізацію регіонів та збільшення чисельності населення у містах. Зростання числа міських споживачів води та зростання рівня споживання води населенням міст призводять до значного збільшення попиту на воду [1-2]. У 2012 році 40\% населення планети мали проблеми iз дефіцитом води, а більшість міст світу прагнули до підвищення ефективності менеджменту водними ресурсами (МВР) [4].

Збільшення кількості опадів зменшує невистачу води. Поступове глобальне потеплення прискорює частоту надзвичайних подій, таких як повені та посухи, впливає на обсяг доступної води, збільшує потреби в зрошенні, що оказує негативний вплив на управління водними ресурсами, який з часом буде тільки посилюватися. Глобальні прогнози зміни клімату для 2050-х рр. передбачають у більшості районів підвищення температури на $1,5-3,5^{\circ} \mathrm{C}$ та зменшення опадів на 10-20\%, залежно від пори року [5]. У 2030 р. міська територія, на яку потенційно можуть вплинути зміни клімату, складе 5.55-20.37\% загальної міської площі [6]. Попередні дослідження

\footnotetext{
${ }^{1} \mathrm{https} / /$ www.unece.org/env/indicators.html
}

показали, що вплив опадів на попит на воду був дуже обмеженим, тоді як кореляція потреб у воді 3 температурою повітря була високою [7]. В різних дослідженнях були отримані лінійні і експоненціальні апроксимації залежності потреб у воді від чисельності населення.

Економічне зростання міст збільшує попит на воду. Швидкий економічний розвиток, зумовлений різноманітною промисловою діяльністю, споживає велику кількість прісної води. В країнах, що розвиваються, на промисловість припадає до 80\% загального споживання води у містах. Передові технології здатні переробляти воду та значно скорочувати іiі споживання. Коефіцієнт переробки води в галузях експлуатації нафти та природного газу може досягати $84 \%$, а у виробництві виплавки чорнових металів та прокату - до $95 \%{ }^{2}$. Підвищення ефективності використання води стало важливим засобом для планування витрат обмежених запасів води з урахуванням зростаючих потреб. Різні розрахунки показують, що водозберігаючі крани і каналізаційні прилади можуть заощадити 30-50\% і 26-60\% споживання води відповідно [3], а краплинне зрошування паркових насаджень може заощадити 35-70\% порівняно 3 поверхневим. Раціональні персональні обмеження у використанні води, які викликані стурбованістю людей в охороні навколишнього середовища та водних ресурсів, допомагають використовувати на $24 \%$ менше води. Серед регуляторів зменшення споживання $є$ збільшення цін, ущільнення житла та мотивація населення [8]. Останній регуля-

\footnotetext{
2 http://www.stats.gov.cn/english/, https://www.nigerianstat.gov.ng/, https://stat.gov.pl/en/
} 
тор вживається як К-фактор, який є багатофакторним компонентом в моделях соціальної поведінки [9] і використовується для представлення окремих акторів в динамічній адаптивній системі, зокрема в агентному моделюванні (АМ), методах системної динаміки (СД) [10] та ряді інших. Моделі СД широко застосовуються в галузі менеджменту міськими водними ресурсами за умовами зростання чисельності населення [11-12], економічних, глобальних змін клімату [13] та груп факторів [3]. Для ефективного використання методів АМ, СД, які досліджують нелінійну динаміку складних багатокомпонентних систем і можуть давати прогнози їх сталого розвитку, потрібна детальна інформація у вигляді системи безперервного моніторингу (CM), яка зберігала би потрібну інформацію в БД для їі подальшої обробки.

Методи СД показали свою високу ефективність в системах МВР на прикладах окремих великих міст, районів, земель і річкових систем [3; 14-17]. Було показано, що впровадження комплексних заходів 3 охорони води та підвищення готовності населення до збереження води може на 17-28\% (залежно від наявних ресурсів) зменшити загальні витрати води в масштабах всього району.

Таким чином, водні ресурси міста зазнають значного тиску від урбанізації, зростання населення, глобальних змін клімату. МВР потребує відповідних математичних моделей динамічної взаємодії між потребами води та населенням, підприємствами, сільським господарством, очищенням та збереженням води. В даній роботі обговорюються підходи до використання методів СД для МВР на урбанізованій території м. Харків.

Метою даної роботи $\epsilon$ аналіз інформації з відкритих джерел щодо витрат і потреб прісної води на урбанізованих територіях великих міст для розробки онлайн ресурсу, який може забезпечити швидкий доступ до кількісної інформації та засобам ії обробки, аналізу методами статистики, математичного моделювання, механіки рідини та СД, і поширення висновків для своєчасного прийняття рішень на різних рівнях, порівняно $з$ досвідом світової практики. На сьогодні метод СД використався для даних України тільки для системи річок Харків-Лопань-Уди [10; 14], p. Сіверський Донець [15] і Південний Буг [18-20].

\section{Виклад основного матеріалу \\ Компартментальне моделювання складних гідрологічних систем}

Однією з можливостей інтегрованого гідросис-


різні гідравлічні компартменти. Чисельні розрахунки фізико-хімічних процесів у кожному компартменті можуть вимагати різної часової (від секунд до тисячоліть) та просторової (від нінорівня до плане- тарного масштабу) дискретизації з використанням різних геометричних моделей та різних числових методів (скінченні різниці, скінченні елементи, скінченні об'єми), і головним питанням, що виникає, є метод зчеплення компартментів та процесів в них. Серед відкритих джерел інформації є бази гідрологічних, кліматичних, геофізичних, екологічних даних, математичних моделей фізико-хімічних процесів та комп'ютерних кодів для кожного гідрологічного компартменту (OpenGeoSys ${ }^{3}$, IWAS-Toolbox ${ }^{4}$, QGIS $^{5}$, SAGA-GIS ${ }^{6}$, RIC $^{7}, \mathrm{PRMS}^{8}$ ), а також для обробки даних та моделювання течій рідини (Python, $\mathrm{R}$, OpenFoam).

Гідросистеми можна приблизно розділити на компартменти поверхневих вод, грунту та водоносного шару (рис. 1). Відповідні гідравлічні процеси це осадки у вигляді дощу, снігу та ін., поверхневий стік до річок та озер, потоки річкових вод, ненасичений потік в грунтах, потік підземних вод у пористих середовищах. Крім того, вода може транспортувати природні або антропогенні, реактивні або нереактивні компоненти, та взаємодіяти з атмосферою і біосферою, відкладатись та накопичуватись в грунтах, воді, рослинах. Відповідні моделі і софт включають менеджмент поверхневими водами (Storm Water Management Modeling), процеси переносу в річкових системах (River Modeling), гідрологічні процеси на мезорівні (Mesoscale Hydrologic Modeling), біохімічні процеси Biogeochemical Reaction Network Modeling) та інші.



Рис. 1. Гідросистема та їі компартменти. Схема Джерело: розроблено авторами.

Опади випадають на поверхню, просочуються до грунту, потрапляють у коріння рослин, до поверхневих і грунтових вод. Поверхневий стік води крізь

\footnotetext{
3 https://www.opengeosys.org/

4 https://www.swmath.org/software/13423

5 https://www.qgis.org/ru/site/

${ }^{6} \mathrm{http} / / /$ www.saga-gis.org/en/index.html

7 https://i-ric.org/en/

8 https://www.usgs.gov/software/precipitation-runoff-modelingsystem-prms
} 
сільськогосподарські та урбанізовані поверхні несе 3 собою хімічні компоненти добрив та урбаністичних забруднень відповідно. Значна частина води випаровується $з$ поверхні. Підповерхневі системи безпосередньо пов'язані 3 атмосферою крізь поверхню, поверхневі води і рослини. В літературі представлені як звичайні моделі випаровування крізь насичені/ненасичені пористі поверхні, з поверхні води [21] та - з урахуванням біосферної компоненти - 3 поверхні як однієї крупної рослини (дерева, куща), так і в рамах функціональних моделей кореневих грунтів 3 розподіленими рослинами (трави, зернові та ін.) [22-23]. Розрахунки показують, що течія води в грунті біля коріння впливає на швидкість іiї захоплення рослинами. Існують окремі моделі для сухопутного стоку опадів до поверхневих вод, потоків через руслові (річкові) мережі, для насиченого-ненасиченого підповерхневого потоку та ін. При моделюванні процесів в складних гідрологічних системах окремі моделі повинні бути пов'язані та розв'язуватися разом (див. огляд літератури в [19; 24-25]. Сучасні комп'ютерні програми для моделювання підгрунтової гідрології - це HydroGeoSphere ${ }^{9}$, Feflow ${ }^{10}$ i $\mathrm{OpenGeoSys}^{11}$, а для моделювання зв'язаних компартментів поверхневих і підземних вод - MIKE SHE $^{12}$, MODHMS $^{13}$, GSFLOW ${ }^{14}$, ParFlow ${ }^{15}$.

Велика частина населення Землі залежить від прісної води 3 місцевих водоносних горизонтів, i оцінка ризиків забруднення підземних вод $\epsilon$ центральною темою, коли населення швидко зростає або споживання води перевищує можливості ії поповнення. У багатьох із цих районів ресурси підземних вод стають все більш під загрозою за рахунок вимивання забруднень $з$ неконтрольованих джерел, дифузним просочуванням добрив та продуктів діяльності заводів, фабрик, шахт і транспорту.

Крім того, попадання солоної води погіршує якість підземних вод у прибережних районах. Варіації густини грають ключову роль у динаміці гідродинаміки прибережного водоносного шару, і тому в районах, де стратегії інтегрованого управління водними ресурсами повинні включати морську воду, яка проникає в прибережні водоносні горизонти, іiі перенос та фільтрацію в пористих грунтах в залежності від густини, а також транспорт забруднювачів від випадкових розливів та витоків промислових хімікатів до поверхневих вод.

Таким чином, гідрологічна система розглядається як сукупність компартментів поверхневого

\footnotetext{
${ }^{9}$ https://www.aquanty.com/hydrogeosphere

${ }^{10}$ www.mikepoweredbydhi.com/

${ }^{11} \mathrm{https}$ ://www.opengeosys.org/

${ }^{12}$ https://en.wikipedia.org/wiki/MIKE_SHE

${ }^{13} \mathrm{https} / / /$ www.hgl.com/softwareproducts-new/modhms/

${ }^{14} \mathrm{https}$ ://www.usgs.gov/software/coupled-ground-water-and-surface-

water-flow-model-gsflow

${ }^{15}$ https://parflow.org/
}

стоку; переносу в річкових мережах; накопичення в озерах, ставках, болотах; перенос від/до резервуарів солоної води з урахуванням стратифікації шарів води; фільтрація в ненасиченій/насиченій зонах; переніс в біосферному шарі (грунт $\rightarrow$ коріння рослин $\rightarrow$ листя $\rightarrow$ атмосфера); транспорт до грунтових вод та артезіанських свердловин питної води; відбір технічної води для поливання сільськогосподарських земель та на потреби міст; відбір питної води для населення та сільськогосподарських тварин. Межі між компартментами визначаються за геофізичними та гідрологічними даними для даної області (властивості поверхні; детальні карти річкових систем, озер і т.д.; глибина залягання та склад грунтів; локалізація шару грунтових вод).

При 3d-розрахунках в кожній області результати обчислень на спільних границях зв'язуються послідовними та неітераційними схемами зчеплення, які зв'язують потоки маси, концентрацій і тепла (за необхідністю) між компартментами за допомогою геометрично зв'язаних умов (баланс відповідних потоків), наявність позитивних/негативних джерел води, забруднень, тепла; граничних умов непроникнення на водоупорах і випаровування на поверхнях (водних, рослинних, грунтових).

Такий спосіб проведення розрахунків дає можливість отримати найдетальнішу різноманітну гідрологічну інформацію для МВР, але потребує значних ресурсів у вигляді розрахункового часу, комп'ютерних міцностей для накопичення інформації у базах даних, проведення чисельних розрахунків i візуалізації результатів на 4d-картах місцевості (3d геометрія + зміни за часом швидкостей руху рідин, випадання опадів, накопичення забруднень та ін. динамічних процесів з різними характерними часами). Для зменшення ресурсоємності гідрологічних систем запропоновані мезомасштабні гідрологічні моделі, які враховують процеси фільтрації та переносу «в середньому» і поєднуються з моделями підземних вод [19-20]. Для забезпечення регульованого інструменту для моделювання довільного реактивного транспорту був розроблений симулятор мережі біогеохімічних реакцій (Biogeochemical Reaction Network Simulator, BRNS) [26].

B результаті можна отримати зв'язаний набір ефективних інструментів 3 гнучкими перехресними зв'язками (рис. 2), що дасть можливість інтегрованого аналізу сценаріїв у даному регіоні та обгрунтованого прийняття рішень. Базу даних треба постійно поповнювати та уточнювати результати моделювання. Приклад сукупності дій наведений в табл.1.

Умовно різні інструменти в системі об'єднані в три зв'язані між собою рівні:

1. Датчики, реєстратори даних, розумні лічильники, інші інтелектуальні електричні пристрої, які використовуються для отримання інформації про 
стан, властивості та будь-які фізичні параметри 3 інфраструктури водопостачання на всіх рівнях.

2. Рівень інформаційних і комп'ютерних технологій (IT/IC), де всі зібрані дані очищаються, нормалізуються, агрегуються та зберігаються для подальшої обробки та порівняння.

3. Математичний модуль - статистична обробка та аналіз даних вимірювань; генерація та перевірка гіпотез; планування та проведення активних експериментів; чисельні розрахунки процесів переносу в компартментах; візуалізація і аналіз розрахункових даних; розрахунки інтегральних параметрів та безрозмірних індексів.

4. Модулі систем підтримки прийняття рішень (decision support system, DSS) і презентації результатів у вигляді діаграм, таблиць, схем, карт, $3 \mathrm{~d}$ або $4 \mathrm{~d}$ візуалізації.

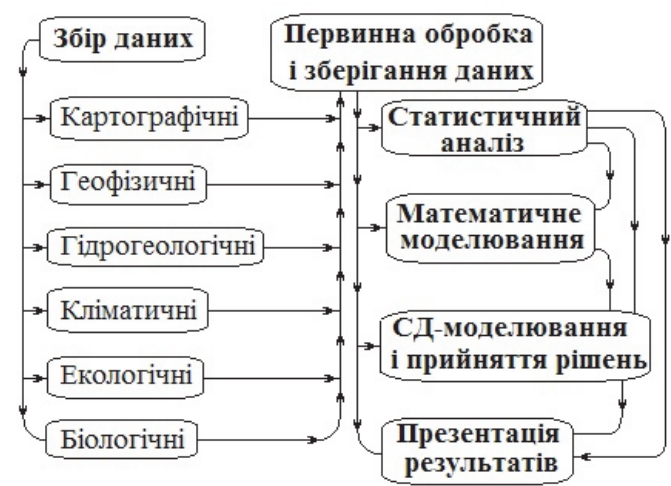

Рис. 2. Компоненти системи МВР і зв'язки між ними Джерело: розроблено авторами.

Найважливіші питання, які розв'язують за допомогою такого підходу, - це прогнози потреб та наявності запасів питної води в регіоні, якість питної води, накопичення забруднень, можливості природного самоочищення вод і грунтів та необхідність додаткових штучних засобів та підходів, наслідки надмірного викачування води, підтоплення будинків в приморських/річкових ділянках та багато інших.

Ці питання суттєво відрізняються в залежності від обраного району. Наприклад, для проведення заходів на регіональному рівні потрібно:

1) Визначення регіональних цілей для загального управління водним циклом.

2) Регіональні/субрегіональні дослідження стану поверхневих та підземних вод.

3) Картування водних ресурсів, водозборів, водозалежних екосистем та існуючих дренажних мереж.

4) Визначення субрегіону(ів), яке залежить від води та потребує менеджменту.

5) Історична оцінка землекористування і оцінка пропонованих змін у землекористуванні.

6) Планування джерел води та визначення варіантів повторного використання на основі регіонального водного балансу.
7) Підготовка регіональної стратегії управління водними ресурсами (включаючи стратегічний план водовідведення).

8) Підготовка регіонального стратегічного плану з урахуванням регіональної/субрегіональної інформації та стратегії водних ресурсів.

Таблиця 1

Сукупність дій місцевої стратегії управління водними ресурсами в рамках запропонованої моделі СД

\begin{tabular}{|c|c|}
\hline Дії & \multicolumn{1}{|c|}{ Склад дій } \\
\hline Моделювання & Визначення всіх компонентів системи балансу
\end{tabular}

водного балансу води до та після внесення змін, для забезпечення зменшення потреби в питній воді шляхом врахування цільового використання (каналізація, прання, гаряча вода, опалення, господарські праці, город, газон і т.п.).


екосистеми та надання більш детальної оцінки, де необхідно.


здоров'я

Моніторинг екологічного здоров'я та гідрологічного режиму середовищ, які залежать від води. Сценарій попереднього розвитку цих середовищ повинен підтримуватися і після внесення змін.

Історична оцін- Обговорення попереднього використання земель ка землекорис- та можливого впливу на якість поверхневого тування як ця проблема буде вирішена запропонованою новою системою.

Визначення площини кислих, солоних, забруднених грунтів, які мають високий ризик. Там, де такі грунти існують, треба визначити відповідну стратегію управління для виправлення.

Моніторинг та Визначення поточного стану ресурсу на місцемоделювання вому рівні (GPS-локація, якість води/грунту/ підземних вод повітря, швидкість та ін.)

Перевірка мінімізації потенційних впливів на підземні води, грунти та біосферу, які залежать від води.

Оцінки потенціалу короткочасної мобілізації поживних речовин та забруднювачів, що $\epsilon$ результатом будівельних або ін. робіт, а також довгостроковий вплив на якість підземних вод від розвитку економіки/транспорту і т.д. Визначення шляхів забруднення.

Перевірка необхідності контролю рівня грунтових вод або дренажу надр, де це пропонується, ідентифікуючи ймовірні зміни рівня підземних вод.

Вивчення потенціалу використання мілководних підземних вод як не питного джерела.

Моніторинг та Моделювання заплав та заболочених земель для моделювання визначення мінімальних будівельних рівнів, поверхневих перешкод для руху та змін рівня води.

вод

Моніторинг швидкостей існуючих поверхневих водних потоків для встановлення поточних потреб. Визначення шляхів керування потоками після внесення змін для досягнення потрібних об'ємів водозбору.

Моделювання дренажу для визначення детальних потреб у землі та можливостей повені, необхідних для подолання великих та незначних штормів, снігопадів і т.п.

Моніторинг розташування і стану шляхів поверхневих водних потоків, місць зберігання паводкових вод та дренажної системи.

Виявлення потенційного впливу на захищені екосистеми поверхневих вод.


потоків в сто- води.

ках i дренаж- Визначення поточної кількості течій, яка необних системах $\quad$ хідна для встановлення вимог нормального розвитку (тобто витрати на 1 рік). 
Таким чином, ключовими принципами інтегрованого управління водним циклом та заданій териTopiï $\epsilon$ :

1. Врахування всіх водних ресурсів, включаючи стічні води, при плануванні водокористування.

2. Інтеграція планування використання води та землі.

3. Стійке та справедливе використання всіх джерел води з урахуванням потреб усіх водокористувачів, включаючи громаду, промисловість та навколишнє середовище.

4. Інтеграція водокористування людини та природних водних процесів.

5. Повна інтеграція використання та управління природними ресурсами.

Головними підходами до забезпеченні виконання цих принципів $є$ :

1. Керування водним режимом

1.1. Підтримування належного рівню водоносного шару, показників поповнення та характеристик поверхневих вод відповідно до призначеного корисного використання.

1.2. Стійке управління поповненням підземних вод.

1.3. Запобігання пошкодженню повенями у розвинутих районах.

1.4. Запобігання надмірній ерозії водних шляхів, схилів та берегів.

2. Підтримування i, де це можливо, покращення якості води

2.1. Мінімізація завантаження водних осадів.

2.2. Захист прибережної рослинності.

2.3. Мінімізація експорту забруднюючих речовин, таких як фосфор, азот, важкі метали та ін. у поверхневі або підземні води.

2.4. Запобігання процесам закислення підземних вод.

2.5. Мінімізація доступу та впливу забруднень 3 каналізації.

3. Заохочення збереження води

3.1. Мінімізація імпорту та оптимізація схеми використання води.

3.2. Сприяння сталому використанню дощової води.

3.3. Сприяння сталому повторному використанню та переробці стічних вод.

3.4. Зниження вимог до зрошення.

3.5. Сприяння можливостям локалізованого постачання.

4. Підтримування i, де це можливо, підвищення екологічних, рекреаційних та культурних цінностей, які пов'язані з водою.

\section{Математичне моделювання менеджменту водними ресурсами регіону}

Компартментальні математичні моделі МВР базуються на рівняннях балансу між джерелами во- ди та іiі використанням за умовами сільськогосподарського i/або урбанізованого регіону.

Побутовий водний сектор, як основний споживач води, розширюється завдяки зростанню населення, яке, у свою чергу, $є$ функцією кількох змінних, включаючи народжуваність (birth rate, $B$ ), смертність (death rate, $D$ ), міграцію (migration rate, $M$ ) в момент часу $t$, який визначається в місяцях, у вигляді

$$
N(t+1)=N(t)+B(t)+M(t)-D(t),
$$

де $N(t)$ - кількість населення.

Оскільки 2020p. є винятковим із-за пандемії COVID-19, для розрахунків приймемо дані за попередній рік. Відповідно до статистичних даних ${ }^{16}$, у 2019 р. річний рівень народжуваності, смертності та міграції були $B_{r}=1.0868 \%, D_{r}=1.54 \%, M_{r}=0.0866 \%$. Прогнози значень $B(t), M(t), D(t)$ в кожному наступному року базуються на статистичних апроксимаціях, даних по віковому складі населення та тривалості життя.

Найважливішим компонентом $\epsilon$ масовий баланс води. Різниця між водопостачанням та потребами у воді визначається як дефіцит води. Вода затребувана побутовими, медичними, сільськими, озелененими, промисловими та міськими службами, а іiі баланс визначається як

$$
\begin{aligned}
W(t+1) & =W(t)+S W(t)+G W(t)+ \\
& +C W(t)-U(t)-L W(t),
\end{aligned}
$$

де $W$ - доступний об'єм води, $S W(t)$ і $G W(t)$ - подача води 3 поверхневих (surface water) та підземних (groundwater) вод відповідно, $C W$ - збереження води за допомогою заходів контролю витоків (controlled water), $U W$ - загальна кількість води, що виділяється на всі потреби (used water), і $L W$ - це втрати води (lost water). Втрати води включають частку від загальної кількості води, яка не використовується споживачами, і складаються з фізичних та нефізичних втрат. Внутрішне споживання води на території України оцінювалося як: 52.4\% на сільське господарство, 35.3\% на промисловість, 12.1\% на домашнє споживання, 250 л на день на душу населення, у тому числі 3.5 л питної бутильованої води на місяць на душу населення, площа земель, які можна зрошувати для аграрних цілей - 5.5 млн. га, у тому числі фактично зрошувані землі - 0.73 млн. га.

Загальне рівняння гідрогеологічного балансу води в регіоні

$$
\Sigma Q_{\text {in }}(t)-\Sigma Q_{\text {out }}(t)=\Delta V(t),
$$

де $\Sigma Q_{i n}$ та $\Sigma Q_{o u}$ - це сумарні поповнення до та відтік з водоносного шару відповідно, а $\Delta V-$ зміни в наявному обсязі водоносного шару, який потребує перманентного контролю.

\footnotetext{
16 https://countrymeters.info/ru/Ukraine
} 
Ефективні змінні в потенціалі водоносного шаpy $\left(\Sigma Q_{i n}\right)$ визначаються як:

$$
\begin{aligned}
\Sigma Q_{i n}(t) & =Q_{p w}(t)+Q_{u w}(t)+Q_{s w}(t)+ \\
& +Q_{r}(t)-Q_{v p}(t)-Q_{p l}(t),
\end{aligned}
$$

де $Q_{p w}$ (percolated water) - просочена вода від опадів, $Q_{u w}$ (underground water) - приплив підземних вод до водоносного шару, $Q_{s w}$ (surface water) - поповнення річок та інших поверхневих джерел води, розраховується як різниця притоку і відтоку на границях регіону, а $Q_{r}$ (returned water) - поповнення зворотним потоком (очищення, опріснення), $Q_{v p}$ випаровування 3 поверхні і $Q_{p l}$ - поглинаннями рослинами зелених насаджень (розраховуються за таблицями).

Кількість опадів і стоків у системі водоносного шару регіону можна взяти з існуючих кліматичних, екологічних, поточних досліджень. Зворотний потік $\epsilon$ функцією різних змінних і визначається як

$$
\begin{aligned}
Q_{r}(t) & =A R(t)+L R(t)+D R(t)+ \\
& +I R(t)+S R(t)+T R(t),
\end{aligned}
$$

де $A R$ i $L R$ - стоки від сільськогосподарського (agriculture return) та ландшафтного (landscape return) використання, відповідно, що становить разом $20 \%$ від споживання; $I R$ (industrial return) - від промисловості та послуг споживання, $\sim 32 \%$; $D R$ (domestic return) - від внутрішнього споживання, $\sim 70 \%$; SR (surface return) - зворотний потік води 3 джерел, які забезпечують водою сільське господарство, $225 \%$ від загального використання; $T R$ (town return) - витік із міської водорозподільної мережі, $\sim 25 \%$ від загальної кількості води, що надходить до побутової системи розподілу.

Значна частина споживання води в населених пунктах попадає до водоносного шару в основному через свердловини, оскільки міська система збору стічних вод $\epsilon$ неповною. Досконала система збору міських стічних вод $є$ одним із факторів, що зменшує зворотний потік до водоносного шару. Стічні води будуть очищуватися на основних та місцевих очисних спорудах і будуть використовуватися для різних споживань, включаючи сільське господарство, озеленення, промисловість та штучне поповнення водоносного шару.

Загальні витрати водоносного шару можна виразити як:

$$
\Sigma Q_{\text {out }}(t)=Q u o+Q d+Q d r,
$$

де $Q u о$ - об'єм витоку підземних вод через його межу, $Q d$ - загальний об'єм витягнутого з водоносного шару через свердловини, канали і джерела, які використовуються для різного водоспоживання, $Q d r-$ об'єм стічної води з водоносного шару через високі рівні підземних вод в деяких міських районах.

Маючи обсяги скидання та поповнення водоносного шару, зміни в сховищі підземних вод можуть бути визначені наступним чином:

$$
\Delta V=A \cdot S \cdot \Delta h,
$$

де $A$ - поверхня водоносного шару в км ${ }^{2}, S-$ коефіцієнт зберігання водоносного шару, $\Delta h-$ середня зміна рівня підземних вод у метрах.

Рівняння балансу поверхневого стоку води:

$$
\Sigma Q_{R}=\Sigma Q_{m}+\Sigma Q_{u},
$$

де $\Sigma Q_{R}$ - загальний стік в межах регіону, $\Sigma Q_{m}$ загальний приплив з районів, які розташовані вище за течією, $\Sigma Q_{u}$ - загальний стік, що продукується в межах регіону.

Загальний приплив може бути визначений за допомогою даних гідрометричних датчиків, а кількість $\Sigma Q_{u}$ можна розрахувати як:

$$
\Sigma Q_{u}=Q_{p}+Q_{A q}+Q_{W},
$$

де $Q_{p}, Q_{A q}, Q_{W}$ - стоки, які утворюються відповідно з опадів, каналів постачання SW та стічних вод.

Стік $Q_{p}$ залежить від площі поверхні регіону, річної кількості опадів (дощ, град, сніг, паморозь, туман, роса) і коефіцієнту міського стоку ( $\sim .6$ для великих міст), враховуючи типове поєднання землекористувань (дахи, ландшафти, парки, вулиці тощо). Співвідношення загального внеску стічних вод до поверхневого стоку $15 \%$.

Таким чином, підстановка рівнянь (4)-(9) в (3) дає загальне рівняння наявних водних ресурсів регіону, а рівняння (1) відповідає зростаючим потребам регіону. Після підстановки в (3)-(9) усіх гідрологічних, метеорологічних, кліматичних, грунтових, економічних та ін. даних співставлення рівнянь (1) i (3)-(9) дає можливість оцінки різних сценаріїв впливу розвитку регіону за запаси питної води $\mathrm{i}$ планування потрібних заходів МВР.

\section{Валідація компартментальної моделі}

Система рівнянь (1)-(9) описує динамічну систему в дискретних змінних (дані з кроком $t=1$ міс. або $t=1$ рік). Динамічні моделі часто чутливі до своїх параметрів і потребують калібрування/валідацію шляхом порівняння динаміки моделі з вимірюваними часовими рядами, наприклад, $h(t)$ в даному регіоні. Оскільки жодна математична модель не може дати $100 \%$ точність, ступінь, в якій модель відповідає даним вимірювань, визначає іiі якість та ефективність. Валідація залежить від ступеня визначеності моделі до поставлених цілей, наприклад, для оптимізації витрат води, своєчасного поповнення резервуару грунтових вод і т.д. Валідація моделі базується на тестуванні ії̈ структури, внутрішньої несуперечливості і точності чисельних розрахунків. 
I. Тест структури моделі. Узгодженість структури моделі та фактичної системи є однією з основних вимог будь-якої процедури моделювання. Тестування структури моделі проводимо на початкових етапах моделювання так, щоб структура моделі зберігалася до кінця облічень за часом $(t=1,2,3, \ldots)$.

II. Тест граничних умов. Цей тест перевіряє стабільність роботи моделі при заданих граничних умовах і оцінює достовірність результатів. Наприклад, коли чисельність населення є фіксована, внутрішній попит на воду не змінюється. За умовами, коли швидкість поповнення водоносного шару за рахунок зворотного потоку із зрошувальних, промислових та сфери послуг, а також прямих опадів та поверхневого стоку збалансовані, сума всіх потоків нульова.

III. Тест надійності моделі. У цьому тесті поведінка моделі порівнюється з часовими рядами даних реальних вимірювань. Цей тест визначає, наскільки обчислені часові ряди відповідають спостережуваним даним.

\section{Результати та їх обговорення}

Для проведення тестів I-III потрібні набори даних для всіх величин, які входять до (1)-(9). Такі дані опубліковані для різних регіонів Китаю [1-3; 13], деяких країн Свропи [5; 9; 18] і Азії [17; 26]. Для валідації моделі були використані саме такі дані i результати тесту III наведені на рис. 3. Таким чином, модель добре відображає зміни динаміки системи (зростання-спад) та кількісно відповідає даним вимірювань. Аналогічні висновки були отримані i для тестів I і II, так само як і у інших авторів [1-3; $13 ; 18]$.



Рис. 3. Результати валідації моделі (тест 3) у вигляді залежності безрозмірного об' $є$ му $V^{\circ}=V / \mathrm{V}_{0}$ запасів грунтових вод (1) і загальних потреб в воді (2); $V_{0}=V(0), t_{0}=2020 \mathrm{p}$.

Джерело: розроблено авторами.

Далі модель буда використана для умов Харківської області, для якої дані динаміки чисельності і вікового складу населення, інформація про грунти і землекористування, кліматичні i метеорологічні умови, гідрологічні характеристики річок басейнів p. Дон і Дніпро (Сіверський Донець, Харків, Лопань, Уди та ін.) на межі області, водовикористання та ряд інших відомі з доповідей і статистичних таблиць [27], які є у відкритому доступі ${ }^{17}$. Недостатні коефіцієнти в (2), (4), (6), (8) екстраполювалися 3 даних інших країн для регіону зі східними соціальноекономічними показниками $[1-3 ; 5 ; 9 ; 13 ; 17-18 ; 26]$.

Порівнювався стандартний сценарій (I) (середній рівень опадів, незмінні темпи зростання показників водокористання) 3 несприятливим сценарієм підвищена середньорічна температура на $1^{\circ}$ i $2^{\circ}$ зі зниженням кількості опадів в 2 і 3 рази (сценарії II і III відповідно), а також наслідки введення наступних заходів: введення мережі збору стічних вод плюс проекти прямого поповнення запасів (IV), введення проектів міжбасейнового водопостачання (V), оновлення/підтримка водорозподільчої мережі (VI), зменшення дефіциту води за рахунок економії (VII), а також сценарії VIII=IV+V, IX=VIII+VI, X=IX+VII. Результати розрахунків наведені на рис. 4 , а-е.




a




6

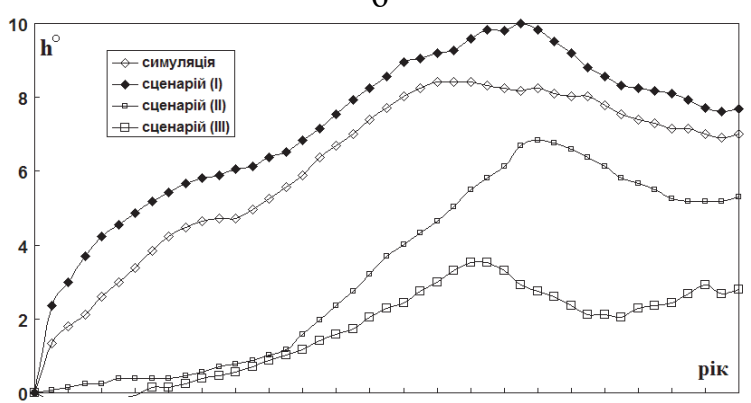



B

Рис. 4. Вплив різних сценаріїв на прогнози змін об'єму грунтових вод (a); безрозмірний рівень опадів (б); рівень грунтових вод (в) (початок)

${ }^{17}$ kh.ukrstat.gov.ua, vodokanal.kharkov.ua, www.unece.org 



Рис. 4. Вплив різних сценаріїв на прогнози змін об'єму грунтових вод (а); безрозмірний рівень опадів (б); рівень грунтових вод (в); об'єм всієї доступної воді (г); об’єм наявних грунтових вод (д (закінчення)

Джерело: розроблено авторами.

Розрахований за моделлю об’єм грунтових вод (у безрозмірних координатах, приймаючи за початкове значення станом на 2013 р.) добре відповідає даним оцінок за результатами вимірювань (20132018 рр.), а прогнозована динаміка у разі потеплення клімату і істотного зменшення рівню опадів якісно відповідає навантаженню на систему водопостачання за таких умов (рис. 4 , а).

Криві поверхневого стоку (опади) $Q_{p w}^{\circ}(t)$, які відомі з даних регулярних вимірювань (1993-2018 pp.), добре відповідають результатам розрахунків (рис. 4,6$)$, особливо приймаючи до уваги, що деякі коефіцієнти моделі були взяті як середні значення за даними інших країн, а не України. Слід зазначити, що обидві криві відповідають не кількості опадів, а тієї долі доступної води (SW i GW), яка пов'язана 3 постачанням опадів до системи водопостачання.

Таким чином, за умовами прогнозованих темпів зростання населення, розвитку промисловості, сільського господарства, сфери послуг і т.д. прогнозований вплив глобального потеплення клімату за результатами чисельних розрахунків за моделлю виявляє значний вплив на рівень запасів грунтових вод, висоту шару підземних вод и об'єми доступної для використання питної та технічної води.
Східні зміни обчислені для умовної висоти шару грунтових вод $h(7)$ (рис. 4, в). Явної кореляції між рис. 4, б, в не спостерігається, тому що в моделі $\epsilon$ єдиний резервуар підземних вод 3 висотою $h=$ const, тоді як реальні значення $h$, які вимірюються в дискретному наборі свердловин, дуже відрізняються в межах регіону і залежать від типу грунтів i ландшафту.

За наявності впливу наслідків глобального потепління ще 31993 р., на сьогодні ми могли б вже відчувати значну нехватку водопостачання навіть у найбільш дощові та сніжні роки (рис. 4, в).

Негативні наслідки кліматичних змін або несподіваних посух можна значно зменшити за рахунок впровадження різних заходів (сценарії IV-X, див. вище), які прийняті за стандарти у різних країнах світу $[1-3 ; 5 ; 8 ; 13 ; 17 ; 26]$. На рис. 4 , г, д показано, як за рахунок впровадження одного з заходів (сценарії IV-VII) вдається трохи пом'якшити негативний вплив кліматичних змін, особливо коли приймаються кілька (сценарії VIII-IX) або всі (сценарій $\mathrm{X)}$ прийняті на сьогодні заходи. Несподівано, що при впровадженню всіх засобів прогнозована підтримка об' єму наявних грунтових вод на сьогоднішньому рівні (рис. 4, д), незважаючи на передбачене зростання економіки. Слід зазначити, що в моделі були використані дані негативних темпів зростання чисельності населення України, які були визначені за 2012-2018 рр. і пов'язані з різними винятковими факторами. Крім того, значного впливу завдає пандемія вірусу COVID-19, вплив якої на багато параметрів 3 (1)-(9) передбачити неможливо.

\section{Висновки}

В роботі сформульовані міждисциплінарні підходи до розв'язання задач МВР на урбанізованих територіях. Наведена детальна математична модель, яка враховує усі притоки/відтоки води в природі та водокористуванні, яка дозволяє обчислювати і прогнозувати рівень запасів підземних та поверхневих вод при різних сценаріях розвитку регіону і змін клімату, а також розробляти відповідні засоби МВР. Показано, що модель добре відповідає даним спостережень за 1993-2018 рр. і дозволяє робити фізично обгрунтовані висновки про вплив можливих глобальних змін клімату на поповнення запасів питної і технічної води в підземних та поверхневих водах. Виявлено значний вплив впровадження різних заходів економії води, поліпшення ii розподілу, постачанню, очищенню й звороту на об'єми доступної води навіть за умов зростання економіки та негативному впливу кліматичних факторів (високі річні температури, низький рівень опадів, зменшення площини і об'ємів транспірації рослин та ін.)

Напрям подальших досліджень пов'язаний зі збором бази даних для цілей МВР, з більшою дета- 
лізацією розробленої моделі з використанням даних для різних областей України і порівняння результатів з аналогічними, що були отримані для країн Св-

\section{Список літератури}

1. Wu P. Challenges for sustainable urbanization: a case study of water shortage and water environment changes in Shandong, China / P. Wu, M. Tan // Procedia Environ. Sci. - 2012. - Vol. 13, No. 3. - P. 919-927. https://doi.org/10.1016/ j.proenv.2012.01.085.

2. A system dynamics urban water management model for Macau, China / T. Wei, I. Lou, Z. Yang, Y. Li // J. Envir. Sci. - 2016. - Vol. 50. - P. 117-126. https://doi.org/10.1016/j.jes.2016.06.034.

3. Bao C. Water resources flows related to urbanization in China: challenges and perspectives for water management and urban development / C. Bao, C.-L. Fang // Water Resour. Manag. - 2011. - Vol. 26(2). - P. 531-552. https://doi.org/10.1007 /s11269-011-9930-y.

4. An efficient numerical model for hydrodynamic parameterization in $2 \mathrm{~d}$ fractured dual-porosity media / H. Fahs, M. Hayek, M. Fahs, A. Younes // Adv. Water Resour. - 2013. - Vol. 63(2). - P. 179-193. https://doi.org/10.1016/ j.advwatres.2013.11.008.

5. From climate change impacts to the development of adaptation strategies: challenges for agriculture in Europe / A. Iglesias, S. Quiroga, M. Moneo, L. Garrote // Clim. Chang. - 2011. - Vol. 112. - P. 143-168. https://doi.org/10.1007/s10584011-0344-x.

6. Humpenoder F. Land-use and carbon cycle responses to moderate climate change: implications for land-based mitigation / F. Humpenoder, A. Popp, M. Stevanovic, et al. // Environ. Sci. Technol. - 2015. - Vol. 49. - P. 6731-6739. https://doi.org/ $10.1021 /$ es506201r.

7. Assessing the significance of climate and community factors on urban water demand / M.M. Haque, P. Egodawatta, A. Rahman, A. Goonetilleke // Int. J. Sustain. Built Environ. - 2015. - Vol. 4(2). - P. 222-230. https://doi.org/10.1016/ j.ijsbe.2015.11.001.

8. Kanta L. A mechanistic-stochastic approach to classify water consumers and simulate urban water demand / L. Kanta, E.M. Zechman // World Environmental and Water Resources Congress. Showcasing the Future. ASCE. - 2013. - P. 2281-2290. https://doi.org/10.1061/9780784412947.224.

9. An evolutionary approach to explaining water conservation behavior / D.H. Ilanit Tal, A.J. Figueredo, M. FrasArmenta, V. Corral-Verdugo // Medio Ambiente Y Comportamiento Humano. - 2006. - Vol. 7(1). - P. 7-27. https://doi.org/ 87131-1161.

10. Кізілова Н.М. Підхід системної динаміки до контролю за якістю води на урбанізованих територіях / Н.М. Кізілова, Н.Л. Ричак, Ю.І. Руднєв // Системи обробки інформації. - 2019. - № 4(159). - С. 87-92. https://doi.org/ 10.30748/soi.2019.159.10

11. Cain P.M. Modelling and forecasting brand share: a dynamic demand system approach / P.M. Cain // Int. J. Res. Mark. - 2005. - Vol. 22(2). - P. 203-220. https://doi.org/10.1016/j.ijresmar.2004.08.002.

12. Koch H. Dynamic modeling of water demand, water availability and adaptation strategies for power plants to global change / H. Koch, S. Vögele // Ecol. Econ. - 2009. - Vol. 68(7). - P. 2031-2039. https://doi.org/10.1016/j.ecolecon.2009.02.015.

13. Wang X.J. Impact of climate change on regional irrigation water demand in Baojixia irrigation district of China / X.J. Wang, J.Y. Zhang, M. Ali, et al. // Mitig. Adapt. Strateg. Glob. Chang. - 2014. - Vol. 20. - P. 116-133. https://doi.org/ 10.1007/s11027-014-9594-z.

14. Кизилова Н.Н. Математическое моделирование и прогнозирование динамики речного русла реки Харьков на территории г. Харькова / Н.Н. Кизилова, Н.Л. Рычак // Механика. Научные исследования и учебно-методические разработки. Сб. статей. - Гомель. - 2019. - Вып. 12. - С. 94-99.

15. Кизилова Н.Н. Математическое моделирование и прогнозирование динамики участка речного русла реки Северский Донец / Н.Н. Кизилова, Н.Л. Рычак, А.А. Халин // Bulletin of V. Karazin Kharkiv National University, Series "Mathematical Modelling. Information Technology. Automated Control Systems". - 2019. - No. 43. - P. 30-37. https://doi.org/ 10.26565/2304-6201-2019-43-04.

16. Determinants of residential water consumption: evidence and analysis from a 10-country household survey / R.Q. Grafton, M.B. Ward, H. To, T. Kompas // Water Resour. Res. - 2011. - Vol. 47(8). - W08537. https://doi.org/10.1029/ 2010WR009685.

17. Merchanta M. Analytics driven water management system for Bangalore city / M. Merchanta, M. Kumar, P.N. Ravindra, et al. // Procedia Engineering. - 2014. - Vol. 70. - P. 1137-1146. https://doi.org/10.1016/j.proeng.2014.02.126.

18. Leidel M. Capacity development as a key factor for integrated water resources management (IWRM): improving water management in the Western Bug River Basin, Ukraine / M. Leidel, S. Niemann, N. Hagemann, et al. // Environ Earth Sci. 2012. - Vol. 65(5). - P. 1415-1426. https://doi.org/10.1007/s12665-011-1223-5.

19. Kalbus E. Integrated water Resources management under different hydrological, climatic and socio-economic conditions / E. Kalbus, T. Kalbacher, O. Kolditz, et al. // Environmental Earth Sciences. - 2012. - Vol. 65(5). - P.1363-1366. https://doi.org/10.1007/s12665-011-1330-3.

20. Kalbacher T. The IWAS-ToolBox: Software coupling for an integrated water resources management / T. Kalbacher, J.-O. Delfs, H. Shao, et al. // Environ Earth Sciences. - 2012. - Vol. 65. - P. 1367-1380. https://doi.org/10.1007/s12665-011$1270-\mathrm{y}$.

21. Freeze R.A. Blueprint for a physically-based, digitally-simulated hydrologic response mode / R.A. Freeze, R.L. Harlan // J. Hydrol. - 1969. - Vol. 9. - P. 237-258. https://doi.org/10.1016/0022-1694(69)90020-1.

22. Use of a three-dimensional detailed modeling approach for predicting root water uptake / M. Javaux, T. Schröder, J. Vanderborght, H. Vereecken // Vadose Zone. - 2008. - Vol. 7. - P. 1079-1089. https://doi.org/10.2136/vzj2007.0115.

23. Implementing small scale processes at the soil-plant interface - the role of root architectures for calculating root water uptake profiles / C.L. Schneider, S. Attinger, J.-O. Delfs, A. Hildebrandt // Hydrol. Earth. Syst. Sci. - 2010. - Vol. 14. P. 279-289. https://doi.org/5194/hess-14-279-2010. $-1424 \mathrm{p}$

24. Singh V.P. Kinematic wave modeling in water resources. Surface-water hydrology / V.P. Singh. - Wiley, NY. - 1996. 
25. Sharma S. Hydrological model diversity enhances streamflow forecast skill at short - to medium - range timescales / S. Sharma, R. Siddique, S. Reed, et al. // Water Resources Research. - 2019. - Vol. 1, No. 2. - P. 1510-1530. https://doi.org/ 10.1029/2018WR023197.

26. Modeling complex multi-component reactive-transport systems: towards a simulation environment based on the concept of a knowledge base / P. Regnier, J. O'Kane, C. Steefel, J. Vanderborght // Appl. Math. Model. - 2002. - Vol. 26. P. 913-927. https://doi.org/10.1016/S0307-904X(02)00047-1.

27. Голиков А.П. Харьковская область: региональное развитие: состояние и перспективы: монография / А.П. Голиков, Н.А. Казакова, М.В. Шуба; под ред. чл.-кор. НАН Украины, проф. Бакирова В.С. - Х.: ХНУ имени В.Н. Каразина, 2011. - 328 c. https://core.ac.uk/download/pdf/46593993.pdf.

\section{References}

1. Wu, P. and Tan, M. (2012), Challenges for sustainable urbanization: a case study of water shortage and water environment changes in Shandong, China, Procedia Environmental Sciences, Vol. 13, No. 3, pp. 919-927. https://doi.org/10.1016/ j.proenv.2012.01.085.

2. Wei, T., Lou, I., Yang, Z. and Li, Y. (2016), A system dynamics urban water management model for Macau, China, Journal of Environmentas Sciences, Vol. 50, pp. 117-126. https://doi.org/10.1016/j.jes.2016.06.034

3. Bao, C. and Fang, C.-L. (2011), Water resources flows related to urbanization in China: challenges and perspectives for water management and urban development, Water Resources Management, Vol. 26(2), pp. 531-552. https://doi.org/ $10.1007 / \mathrm{s} 11269-011-9930-\mathrm{y}$.

4. Fahs, H., Hayek, M., Fahs, M. and Younes, A. (2013), An efficient numerical model for hydrodynamic parameterization in 2d fractured dual-porosity media, Advances in Water Resources, Vol. 63(2), pp. 179-193. https://doi.org/ 10.1016/j.advwatres.2013.11.008

5. Iglesias, A., Quiroga, S., Moneo, M. and Garrote, L. (2011), From climate change impacts to the development of adaptation strategies: challenges for agriculture in Europe, Climate Change, Vol. 112, pp. 143-168. https://doi.org/10.1007/s10584-011-0344-x.

6. Humpenoder, F., Popp, A. and Stevanovic, M. (2015), Land-use and carbon cycle responses to moderate climate change: implications for land-based mitigation, Environmental Science Technologies, Vol. 49, pp. 6731-6739. https://doi.org/ $10.1021 / \mathrm{es} 506201 \mathrm{r}$.

7. Haque, M.M., Egodawatta, P., Rahman, A. and Goonetilleke, A. (2015), Assessing the significance of climate and community factors on urban water demand, International Journal of Sustainable Built Environment, Vol. 4(2), pp. 222-230. https://doi.org/10.1016/j.ijsbe.2015.11.001

8. Kanta, L. and Zechman, E.M. (2014), A mechanistic-stochastic approach to classify water consumers and simulate urban water demand, World Environmental and Water Resources Congress Showcasing the Future, ASCE, pp. 2281-2290. https://doi.org/10.1061/9780784412947.224.

9. Ilanit Tal, D.H., Figueredo, A.J., Fras-Armenta, M. and Corral-Verdugo, V. (2006), An evolutionary approach to explaining water conservation behavior, Medio Ambiente Comportamiento Humano, Vol. 7(1), pp. 7-27. https://doi.org/87131-1161.

10. Kizilova, N.N., Rychak, N.L. and Rudniev, Yu.I. (2019), "Pidkhid systemnoji dynamiky do kontrolju za jakistju vody na urbanizovanykh terytorijakh" [The approach of system dynamics to water quality control in urban areas], Information Processing Systems, No. 4(159), pp. 87-92. https://doi.org/10.30748/soi.2019.159.10.

11. Cain, P.M. (2005), Modelling and forecasting brand share: a dynamic demand system approach, International Journal on Research in Marketing, Vol. 22(2), pp. 203-220. https://doi.org/10.1016/j.ijresmar.2004.08.002.

12. Koch, H. and Vögele, S. (2009), Dynamic modeling of water demand, water availability and adaptation strategies for power plants to global change, Ecological Economy, Vol. 68(7), pp. 2031-2039. https://doi.org/10.1016/j.ecolecon.2009.02.015.

13. Wang, X.J., Zhang, J.Y. and Ali, M. (2014), Impact of climate change on regional irrigation water demand in Baojixia irrigation district of China, Mitigation and Adaptation Strategies for Global Change, Vol. 20, pp. 116-133. https://doi.org/ $10.1007 / \mathrm{s} 11027-014-9594-z$.

14. Kizilova, N.N. and Rychak, N.L. (2019), "Matematycheskoe modelyrovanye y proghnozyrovanye dynamyky rechnogho rusla reky Kharjkov na terrytoryy g. Kharkova" [Mathematical modeling and forecasting of dynamics of the river bed of the Kharkiv river in the territory of Kharkiv], Mechanics: Scientific research and educational and methodical developments, No. 12, pp. 94-99.

15. Kizilova, N.N., Rychak, N.L. and Khalin, A.A. (2019), "Matematycheskoe modelyrovanye y proghnozyrovanye dynamyky uchastka rechnogho rusla reky Severskyj Donec" [Mathematical modeling and forecasting of the dynamics of the Seversky Donets riverbed], Bulletin of V. Karazin Kharkiv National University, Series "Mathematical Modelling. Information Technology. Automated Control Systems", No. 43, pp. 30-37. https://doi.org/10.26565/2304-6201-2019-43-04.

16. Grafton, R.Q., Ward, M.B., To, H. and Kompas, T. (2011), Determinants of residential water consumption: evidence and analysis from a 10-country household survey, Water Resources Research, Vol. 47, pp. 1-14, W08537. https://doi.org/ 10.1029/2010WR009685.

17. Merchanta, M., Kumar, M. and Ravindra, P.N. (2014), Analytics driven water management system for Bangalore city, Procedia Engineering, Vol. 70, pp. 1137-1146. https://doi.org/10.1016/j.proeng.2014.02.126.

18. Leidel, M., Niemann, S. and Hagemann, N. (2012), Capacity development as a key factor for integrated water resources management (IWRM): improving water management in the Western Bug River Basin, Ukraine, Environmental Earth Sciences, Vol. 65(5), pp. 1415-1426. https://doi.org/10.1007/s12665-011-1223-5.

19. Kalbus, E., Kalbacher, T. and Kolditz, O. (2012), Integrated Water Resources Management under different hydrological, climatic and socio-economic conditions, Environmental Earth Sciences, Vol. 65(5), pp. 1363-1366. https://doi.org/10.1007/ s12665-011-1330-3.

20. Kalbacher, T., Delfs, J.-O. and Shao, H. (2012), The IWAS-ToolBox: Software coupling for an integrated water resources management, Environmental Earth Sciences, Vol. 65, pp. 1367-1380. https://doi.org/10.1007/s12665-011-1270-y.

21. Freeze, R.A. and Harlan, R.L. (1969), Blueprint for a physically-based, digitally-simulated hydrologic response model, Journal of Hydrology, Vol. 9, pp. 237-258. https://doi.org/10.1016/0022-1694(69)90020-1.

22. Javaux, M., Schröder, T., Vanderborght, J. and Vereecken, H. (2008), Use of a three-dimensional detailed modeling approach for predicting root water uptake, Vadose Zone Journal, Vol. 7, pp. 1079-1089. https://doi.org/10.2136/vzj2007.0115. 
23. Schneider, C.L., Attinger, S., Delfs, J.O. and Hildebrandt, A. (2010), Implementing small scale processes at the soilplant interface - the role of root architectures for calculating root water uptake profiles, Hydrology and Earth System Sciences, Vol. 14, pp. 279-289. https://doi.org/10.5194/hess-14-279-2010.

24. Singh, V.P. (1996), Kinematic wave modeling in water resources. Surface-water hydrology, Wiley, NY, 1424p.

25. Sharma, S., Siddique, R. and Reed, S. (2019), Hydrological model diversity enhances streamflow forecast skill at short- to medium-range timescales, Water Resources Research, Vol. 1(2), pp. 1510-1530. https://doi.org/10.1029/ 2018WR023197.

26. Regnier, P., O'Kane, J., Steefel, C. and Vanderborght, J. (2002), Modeling complex multi-component reactivetransport systems: towards a simulation environment based on the concept of a knowledge base, Applied Mathematical Modeling, Vol. 26, pp. 913-927. https://doi.org/10.1016/S0307-904X(02)00047-1.

27. Golikov, A.P., Kazakova, N.A. and Shuba, M.B. (2011), "Kharjkovskaja oblastj: reghyonaljnoe razvytye: sostojanye y perspektyvy" [Kharkiv region: regional development: state and prospects], V.N. Karazin Kharkov National University Press, 328 p. available at: https://core.ac.uk/download/pdf/46593993.pdf.

Відомості про авторів:

Кізілова Наталія Миколаӥвна

доктор фізико-математичних наук

професор Харківського національного університету

ім. В.Н.Каразіна,

Харків, Україна

https://orcid.org/0000-0001-9981-7616

Ричак Наталія Львівна

кандидат географічних наук

доцент Харківського національного університету

ім. В.Н.Каразіна,

Харків, Україна

https://orcid.org/0000-0003-1620-3059
Information about the authors:

\author{
Natalya Kizilova \\ Doctor of Physics and Mathematics Sciences \\ Professor of V.N. Karazin \\ Kharkiv National University, \\ Kharkiv, Ukraine \\ https://orcid.org/0000-0001-9981-7616 \\ Natalia Rychak \\ Candidate of Geographic Sciences \\ Associate Professor of V.N. Karazin \\ Kharkiv National University, \\ Kharkiv, Ukraine \\ https://orcid.org/0000-0003-1620-3059
}

\section{ИНФОРМАЦИОННОЕ СОПРОВОЖДЕНИЕ СИСТЕМЫ МЕНЕДЖМЕНТА ВОДНЫМИ РЕСУРСАМИ НА УРБАНИЗИРОВАННЫХ ТЕРРИТОРИЯХ}

Н.Н. Кизилова, Н.Л. Рычак

Проблемы дефицита воды растут в последние годы почти во всем мире в связи с ростом численности населения, особенно в городских районах, а также в связи с масштабными геофизическими проблемами, такими как глобальное потепление климата, физические изменения в тропосфере, что приводит к существенным изменениям в локальных экосистемах. Соответствующие проблемы, стоящие перед обществом, имеют междисциплинарный характер и поэтому требуют соответствующего подхода к их решению. В данной работе приведен обзор наиболее значимых исследований по этой тематике и предложены модели и методы к обоснованному количественному подходу к решению наиболее существенных задач с использованием баз данных геофизической, гидрологической, экологической, экономической информачии, ее обработки и анализа методами статистики, математического моделирования, механики жидкостей и системной динамики, и распространение выводов для своевременного принятия решений на разных уровнях.

Ключевые слова: геоинформатика, экология, урбанистическая территория, водные ресурсы, менеджент, математическое моделирование.

\section{INFORMATION MAINTENANCE OF THE WATER RESOURCES MANAGEMENT SYSTEM ON THE URBANIZED TERRITORIES}

\section{N. Kizilova, N. Rychak}

Problems of water scarcity have been growing in recent years almost worldwide due to population growth, especially in urban areas, large-scale geophysical problems such as global warming, physical changes in the troposphere, leading to significant changes in local ecosystems. Recently a series of sophisticated mathematical methods like multi-agent modeling, swarm intelligence, computational fluid dynamics methods, system dynamics approach and artificial intelligence was found promising to solve such complex dynamical problems. The complex approach needs deep knowledge in geography, geophysics, ecology, geoinformatics, economists, chemists, biologists, mathematicians and CFD-experts working together with governments. This paper provides an overview of the most important recent studies on this topic and offers models and methods for a reasonable quantitative approach to solving the most important problems using databases of geophysical, hydrological, environmental, economic information, its processing and analysis by statistics, mathematical modeling, fluid mechanics and system dynamics, and the dissemination of conclusions for timely decision-making at various levels. The compartmental model that includes the atmosphere, precipitation, biosphere, surface and ground waters, soils and infiltration is presented. The list of available open source software for each compartment is given. The most detailed mathematical model of the water management of the water resources on an urban landscape is presented. The mathematical model is validated based on available data for Kharkov region. Different scenarios of water consumption in the region depending on the population and economy growth are discussed. It was shown, in each scenario the global warming will seriously influence the water supply of the Kharkov region via higher temperature, low air humidity and precipitation rate, that needs urgent measures on the water management.

Keywords: geoinformatics, ecology, urbanized territory, water resources, management, mathematical modeling. 